\title{
Workload and Work Stress on Caring Behavior in nurse on Nursing Services
}

\author{
Nur Hamim \\ Airlangga University \\ Area Pendidika n Pesantren Zainul Hasan Probolinggo, Indonesia \\ Email: hnurhamim.nh@gmail.com
}

Doi:10.5296/ijhrs.v5i3.8236 URL: http://dx.doi.org/10.5296/ijhrs.v5i3.8236

\begin{abstract}
Introduction: Imbalance between the number of personnel and the workload of nurses in a hospital, so that nurses can implement caring behavior in the process of health care.

Objective: The aim of this study is to know is there any relation Workload and Stress Work with Application Behavior Caring Behavior Nurses in Service Nursing In the main hall of hospitals Probolinggo.

Methods: This study uses correlation analytic design with cross sectional approach Comparative. The population in this study were nurses in the Main room number 13 of the respondents, the sampling technique used "Total sampling". The study was conducted on January 5 to February 3, 2014. The instruments used are questionnaires and observation sheets. After the data collected includes the coding of data collection, editing and tabulating, and then analyzed using statistical tests Loglinier.

Results and Analyzed: The results showed the majority of nurses in the main room of the workload being experienced by 7 respondents (53.8\%), experienced moderate job stress as much as 8 respondents (61.5\%), and behave caring as much as 10 respondents (76.9\%). Based on statistics Loglinier Test results showed that the value of $\alpha p$ value of 0.001 with a significance level of 0.05 . Thus, the Jerusalem Bible $p$ value less than $\alpha(0.05)$ so that it can be concluded $\mathrm{H} 1$ accepted which means no relationship Workload and Stress Working with Application Behavior Behavior Nurse Caring Orphanage in Service Keperawatan.

Discussion: Based on this study it can be concluded that there relationship workload and stress of work in the application of behavioral nurse caring behaviors in the nursing care services. Although the nurse workload and stress suffered heavy work, nurses are expected to remain implement caring behavior behavior, so that the client feels safe and comfortable.
\end{abstract}

Keywords: Workload, Work Stress, Caring Behavior, Nurse. 


\section{Background}

Nursing service quality can be achieved either depend on Developments in science and technology today gives positive influence on the health service. The number of the public information received either from print and electronic media, makes people more critical of health service delivery. Society demands greater responsibility from health care providers for various services provided to them. This gives the effect of increased quality health care (Ismar.A, 2004). At the hospital nursing also plays a very strategic, where most health workers are nurses who provide nursing care. Nursing service quality can be achieved either depends on the imbalance between the number of personnel and the workload of nurses in a hospital. High workload that can lead to stress and a decline in the quality of nursing care, so nurses caring behavior does not apply to the health care process (Journal of Nursing Indonesia, 2012).

Quality health care can be seen from the behavior, and skill shown by a nurse or a doctor or other health care provider other than the knowledge they have, Watson (2006) emphasized that all the above elements, perilakulah most important in service quality. Nurses As a profession is challenged to be more responsive to the needs of the client, which has implications for the health or the health care system. This is consistent with the ultimate goal of nursing, which helps clients achieve health potential fully. In helping clients achieve fully the potential health nurses should have a holistic approach. Comprehensive nursing approach, namely the provision of nursing care in the bio, psycho, socio, spiritual is the approach used by nurses. This approach uses the concept and knowledge related to nursing, one of which is caring Behavior. But in fact the field nurse caring behaviors rarely apply by reason of the workload is too much in the process of health care (Watson, 2006).

Of the 160 million EU workers 56\% said they are working with a very high speed, and $60 \%$ said they chased tight deadlines. More than a third did not have a voice on what they're told by their employers to do, and $40 \%$ doing a boring job. This may be the cause of various diseases associated with the job. Work stress is also an important determinant of the onset of depression, the fourth-largest cause of disease worldwide. Depression is expected to occupy the second place after heart disease by 2020 .

Excessive workload is a major source of stress most, 37\% of high workload by a stressful job that has an influence on job dissatisfaction, depression, symptoms psikomatik, and $30-50 \%$ working lethargic work environment is a source of stress, $16 \%$ of nurses leaving the job profession. So that nurses are not able to apply caring behavior behavior during the process of nursing care services (Valen J. Suterland 2010).

Main room WaluyoJati Hospital Kraksaan a first class inpatient room with a capacity of 18 beds. The number of clients hospitalized in August - September 2013 amounted to 79 people. Main diruangan nurses numbered 13 people with the details as civil power, as labor contracts, and as apprentices. Besides 3 served as the head indoor structural, deputy head Rungan, and Clinical Instructor. While three people served as team leader and 7 as nurses. Educational qualifications of nurses in the Main Room is $4 \mathrm{~S} 1$ nursing, 9 D3 nursing. With the number of nurses insufficient proportion increased workload, stress will 
also increase. So nurses caring behavior behavior did not apply to the process of nursing care services.

Watson suggested that the response of each individual to a unique health problems, meaning that in the practice of nursing, a nurse must be able to understand each different response from the client to the agony and providing appropriate health services in each different response. So in this case the nurse is required to deal with a client in any different response which is being or will occur. Moreover, caring behavior can only be demonstrated in interpersonal relationships, the relationship between the nurse with the client, which indicates nurses caring through attention, intervening to maintain the client's health and positive energy given to the client. Watson also found caring behavior includes a commitment to provide nursing care that is based on science.

The attitude of caring behavior according to Watson should be reflected in ten curative factors, namely the establishment of a value system humanism and altruistic, gives confidence and hope to facilitate and improve nursing care holistic, foster a sense sensitive to self and others, to develop a relationship of mutual trust, enhance and receive the expression of positive and negative feelings clients, use of a systematic method of solving problems for decision-making, improved learning and teaching interpersonal, create an environment of mental, social, cultural and spiritual support, provide guidance and satisfying human needs and allow the pressure to be fenomologis order petumbu h late self and maturity of the client can be achieved. In fact the field is usually the workload of nurses is not in accordance with the client's needs. Although the workload is not appropriate but nurses must continue to implement the behavior of caring behavior in the process of providing nursing care to the client, so the client feels comfortable and the nursing care provided to clients in a professional manner and quality.

Nursing is a discipline that develops practical and nurses sebaga issue or profession is challenged to be more responsive to the needs of the client, which has implications for the health or the health care system. This is consistent with the ultimate goal of nursing, which helps clients achieve health potential fully. In helping clients achieve fully the potential health nurses should have a holistic approach. Comprehensive nursing approach, namely the provision of nursing care in the bio, psycho, socio, spiritual is the approach used by nurses. This approach uses the concept and knowledge related to nursing, one of which is caring behavior. In addition to caring workload and level of stressors nurses should also be considered in accordance with the needs of patients, so that nurses can provide professional nursing care and quality to the client (Potter - Perry, 2005).

\section{Research Methods}

The design used in this study is "Cross Sectional Comparative" in which the type of research that emphasize measurement time observation of the independent and dependent variable data only once in a while. The study was conducted in the Main room Probolinggo District Hospital on January 5 to February 32014

The population in this study are all nurses in the Main room number 13 respondents. samples 


\section{Macrothink}

International Journal of Human Resource Studies

ISSN 2162-3058 2015, Vol. 5, No. 3

are taken of all nurses in the Main room as much as 13 respondents. Sampling is used all the nurses in the Main room number 13 respondents, using the technique of "total sampling".

The independent variable in this study is the workload and stress of the nurses. The dependent variable was the response variable or output. Most variable means that the variable will appear as a result of the manipulation of an independent variable. The dependent variable in this study implementation caring behavior behavior of nurses in nursing care services.

Instrument data collection research using observation sheet for nurses and sheets of a questionnaire given to nurses. Nurses were observed by researchers, and given questionnaires to determine the workload and work stress experienced by nurses. After the data collected then performed tabulation, analysis of data and then test Linear Regression using SPSS Window 17.

\section{Results and Data Analysis}

In this chapter, the researchers will present the results and analysis of data on "Relationship Workload and Stress Work With Application Behavior Behavior Caring Nurse In Nursing Services in the Main Room Probolinggo District Hospital ". These results will be grouped into two parts: general data and specific data. General data showing the frequency characteristics of respondents by sex, age, education last displayed in tabular form. Specific data on the frequency display workloads, stress, and observations of nurses caring behavior in tabular form.

Data were collected using observation sheet and a nurse caring behavior questionnaire workload and stress of nurses working in hospitals Probolinggo the Main Room. Tenik k sampling used was total sampling the number of respondents is 13 .

\section{Table 5.1}

The frequency distribution of respondents by age in the Main Room hospitals Probolinggo.

\begin{tabular}{|l|l|l|}
\hline Age & $\begin{array}{l}\text { Frequency } \\
(\mathbf{F})\end{array}$ & $\begin{array}{l}\text { Percentage } \\
(\boldsymbol{\%})\end{array}$ \\
\hline $\mathbf{2 1 - 3 0}$ years & 8 & 61.5 \\
$\mathbf{3 1 - 4 0}$ years & 3 & 23.1 \\
$\mathbf{4 1 - 5 0}$ years & 2 & 15.4 \\
\hline Total & $\mathbf{1 3}$ & $\mathbf{1 0 0}$ \\
\hline
\end{tabular}

Source: Primary Data Questionnaire Research, January 2014. 


\section{Macrothink}

International Journal of Human Resource Studies

ISSN 2162-3058 2015, Vol. 5, No. 3

Based on the table above the majority of nurses in the Main Hospital Probolinggo aged 21-30 years, amounting to 8 respondents $(61.5 \%)$.

\section{Table 5.2}

The frequency distribution of respondents by education last in the Main Room hospitals Probolinggo.

\begin{tabular}{|l|l|l|}
\hline Last education & $\begin{array}{l}\text { Frequency } \\
(\text { F) }\end{array}$ & $\begin{array}{l}\text { Percentage } \\
(\%)\end{array}$ \\
\hline S1 Nursing & 4 & 31 \\
D3 Nursing & 8 & 62 \\
S PK & 1 & 7 \\
\hline Total & $\mathbf{1 3}$ & $\mathbf{1 0 0}$ \\
\hline
\end{tabular}

Source: Primary Data Questionnaire Research, January 2014

Based on the table above most of the main hall of hospital nurses in Probolinggo educated D3 of Nursing, amounting to 8 respondents $(62 \%)$.

\section{Table 5.3}

The frequency distribution of respondents by sex in the Main Room hospitals Probolinggo.

\begin{tabular}{|l|l|l|}
\hline Gender & $\begin{array}{l}\text { Frequency } \\
(\text { F) }\end{array}$ & $\begin{array}{l}\text { Percentage } \\
(\boldsymbol{\%})\end{array}$ \\
\hline Man & 4 & 30.8 \\
Female & 9 & 69.2 \\
\hline Total & $\mathbf{1 3}$ & $\mathbf{1 0 0}$ \\
\hline
\end{tabular}

Source: Primary Data Questionnaire Research, January 2014

Based on the table above most of the main hall of hospital nurses in Probolinggo female totaling 9 respondents $(69.2 \%)$. 


\section{Macrothink \\ International Journal of Human Resource Studies \\ ISSN 2162-3058 2015, Vol. 5, No. 3}

\section{Table 5.4}

The frequency distribution of respondents by workload of nurses in hospitals Probolinggo the Main Room.

\begin{tabular}{|l|l|l|}
\hline Workload & $\begin{array}{l}\text { Frequency } \\
(\mathbf{F})\end{array}$ & $\begin{array}{l}\text { Percentage } \\
(\mathbf{\%})\end{array}$ \\
\hline $\begin{array}{l}\text { Heavy } \\
\text { Workload } \\
\text { Workload } \\
\text { Medium } \\
\text { Workload Light }\end{array}$ & 3 & 23.1 \\
\hline Total & 3 & 53.8 \\
\hline
\end{tabular}

Source: Primary Data Questionnaire Research, January 2014

Based on the table above the majority of nurses in the Main Hospital Probolinggo experiencing moderate workload totaling 7 respondents $(53.8 \%)$.

\section{Table 5.5}

The frequency distribution of respondents by Nurses Job Stress On the Main Room hospitals Probolinggo.

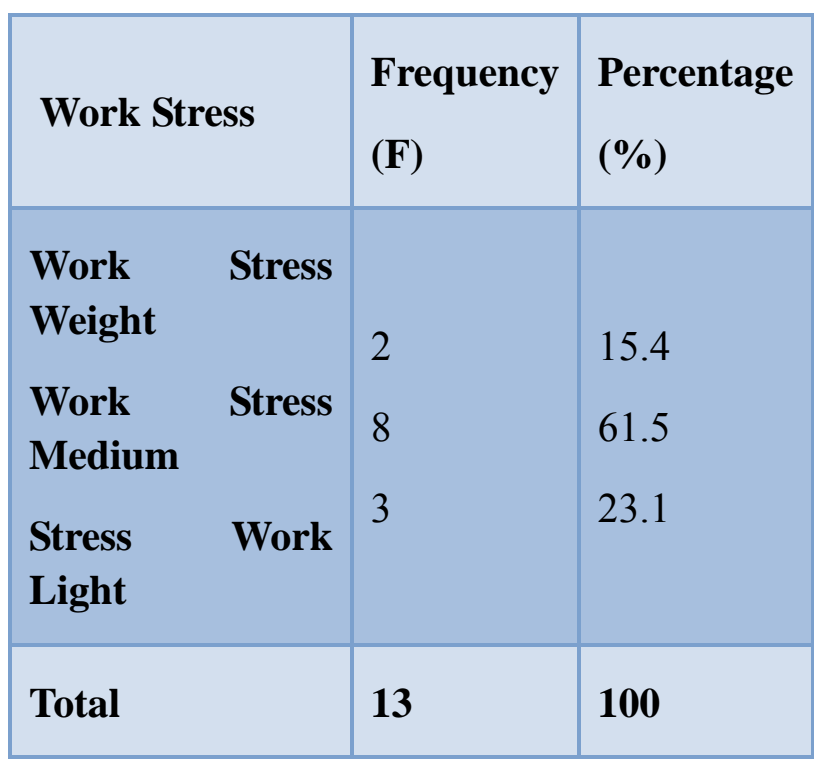

Source: Primary Data Questionnaire Research, January 2014 


\section{Macrothink}

International Journal of Human Resource Studies

ISSN 2162-3058 2015, Vol. 5, No. 3

Based on the table above the majority of nurses in the Main Hospital Probolinggo experienced moderate job stress, amounting to 8 respondents $(61.5 \%)$.

\section{Table 5.6}

The frequency distribution of respondents by Caring Behavior main hall of Hospital Nurses Probolinggo.

\begin{tabular}{|l|l|l|}
\hline $\begin{array}{l}\text { Caring } \\
\text { Behavior }\end{array}$ & $\begin{array}{l}\text { Frequency } \\
(\mathbf{F})\end{array}$ & $\begin{array}{l}\text { Percentage } \\
(\boldsymbol{\%})\end{array}$ \\
\hline Caring & 10 & 76.9 \\
Not Caring & 3 & 23.1 \\
\hline Total & $\mathbf{1 3}$ & $\mathbf{1 0 0}$ \\
\hline
\end{tabular}

Source: Primary Data Questionnaire Research, January 2014

Based on the table above most of the nurses in the Main Room hospitals caring Probolinggo behave totaling 10 respondents $(76.9 \%)$.

\section{Table 5.7}

Workload and Stress Relationship Work With Caring Behaviors Behavior main hall of Hospital Nurses Probolinggo.

\begin{tabular}{lccc}
\hline & Caring & \multicolumn{3}{c}{ Not } \\
& Caring & $\begin{array}{c}\text { Find } \mathrm{n} \\
\text { Load } \\
\text { and Job Stress }\end{array}$ & Total \\
\hline Mild & 0 & 3 & 3 \\
\hline Moderate & 7 & 0 & 7 \\
\hline Weight & 3 & 0 & 3 \\
\hline Total & 10 & 3 & 13 \\
\hline
\end{tabular}

Source: Primary Data Questionnaire Research, January 2014 


\begin{tabular}{|c|c|c|c|c|c|}
\hline Model & $\begin{array}{l}\text { Sum of } \\
\text { Squares }\end{array}$ & df & $\begin{array}{l}\text { Mean } \\
\text { Square }\end{array}$ & $F$ & Sig. \\
\hline Regression & 1,500 & 1 & 1,500 & 20 & .001 \\
\hline Residual & .808 & 11 & .073 & 429 & \\
\hline Total & 2,308 & 12 & & & \\
\hline
\end{tabular}

Based on the results of statistical tests Loglinier Relationship analysis Workload and Stress Work With Behavior Nurses Caring Behaviors In Care Nursing In the main hall of Probolinggo District Hospital in 2014 showed that the value of the $p$ value of 0.001 with $\alpha$ significance level of 0.05 . Thus, the $\mathrm{p}$ value is smaller than $\alpha(0.05)$ so that $\mathrm{H} 0$ rejected and H1 accepted. This means there Workload and Stress Relationship Work With Behavior Nurses Caring Behaviors In Care Nursing In Space Ut hospitals ama Probolinggo

\section{Discussion}

Having done the analysis of the data and look at the results obtained will be discussed further on a few things, namely: 1) The workload of nurses in hospitals Probolinggo main room. 2) Stress nurses working in hospitals Probolinggo main room. 3) Caring behavior hospital nurse in the main room Probolinggo. 4) The relationship workload and stress of working with the application behavior nurse caring behaviors in the nursing care services in the main room Probolinggo Hospital.

\section{Interpretation and Discussion}

\subsection{Workload Nurses Main Room hospitals Probolinggo}

Results of research in getting as much as 7 respondents $(53.8 \%)$ of nurses in the main room of the workload being experienced. Based on these data it can be said the majority of nurses in the main room Probolinggo hospitals experienced moderate workload.

Marquis and Hauston (2006) defines the workload of nurses is all activities or activities performed by a nurse during a stint disuatu unit nursing services. The workload can increase the occurrence of poor communication between nurses with patients, failure of collaboration between nurses and physicians, discharge nurses and nurse job dissatisfaction. To estimate the workload of nurses on a unit, the manager should collect data on: the number of patients admitted to the unit it every day / month / year, condition or level of dependency of the patients in the unit, the average days of treatment, the type of action required the patient, the frequency of each nursing actions are performed, the average time required to provide nursing actions (Gillies, 1999). This is evidenced by the results Trisna (2007), nurse indirect activity is an activity that is widely practiced in the inpatient unit and the factors that affect the workload is the number of patients, number of nurses, the amount of activity.

Based on the above a lot of factors that affect the workload of nurses as nursing patient's condition, the patient's medical condition, characteristics that provide care to patients, nursing actions are given and the work environment. Besides nursing personnel decreased during the client's needs can lead to increased workload of nurses is increasing, resulting in a decrease 
of the quality of service and nurse caringbehavior does not apply to patients. One way to reduce the workload of nurses is higher by providing sufficient labor, both in quality and in accordance with the demands of work.

\subsection{Nurses Job Stress On the Main Room hospitals Probolinggo}

Results of research in getting as much as 8 respondents $(61.5 \%)$ of nurses in the main room were experiencing work stress. Based on these data the majority of nurses in the main room Probolinggo hospitals experienced moderate job stress.

According to Beer and Newman (in Luthans, 2008), work stress is a condition that arises from the interaction between individuals and their work, where there is a mismatch characteristics and changes were not evident that occur in the company. According to Gibson et al (2006), states that job stress is an adaptation response mediated by individual differences and or psychological process which is a consequence of any action from the outside (environment), situations, or events that define the psychological and or physical demands excessive to someone.

Stress at work can be prevented the onset and can be faced without obtaining a negative impact. Stress management is more than just deal with it, namely learning in adaplif and effectively overcome.Almost equally important to know what not to do and what to try. Most people with stress in the workplace due to competition, often vent by working harder excessive. This is not an effective way that does not even produce anything to solve the causes of stress, it will compound the problem further.

To deal with stress in a healthy way or harmonious, certainly many things to be studied. In the face of stress, can be done with three strategies, namely: Minimizing and controlling the sources of stress, neutralize the impact caused by stress, increase personal endurance. Strategies that might be done by controlling the various reactions of both physical, emotional, as well as forms of self-defense mechanism. In forming a defense mechanism can be done in various ways. For example crying, telling the problem to someone else, humor (jokes), rest and so on. Meanwhile, in the face of emotional reactions, is to consciously control their emotions, and social support of the environment. The third strategy, carried out by strengthening oneself, ie with a better understanding of self, understanding others, develop personal skills, exercise regularly, worship, work patterns that teralur and discipline, develop goals and values are more realistic, so it is not stressed that interfere in the conduct of our daily activities. If the level of stressors we can be handled well, the concentration of our work will not be disrupted so that we can carry out our work well, especially providing nursing care services.

\subsection{Caring Behavior Nurse In Hospital Main Room Probolinggo}

Results of research in getting as many as 10 respondents $(76.9 \%)$ of nurses in the main hall apply caring behavior. Based on these data the majority of hospital nurses in the main room Probolinggo apply caring behavior.

According to Watson (2006) Behavior Caring is central to nursing practice because caring a 
dynamic approach, where nurses work to further improve its care to clients. In nursing, caring is a core part which is important especially in nursing practice. Currently, caring is a major issue in nursing professionalism. Many experts nursing reveal the caring theory.

Based on 10 caratif factor behavi or nurses caring, the most dominant is always done by a nurse in the main room is an indicator system humanistic and altruistic values, attitudes respectful, sensitive to self and others, creating a comfortable environment and meet the needs of human dasara. Although from the results, the majority of nurses are already implementing caring behavior behavior, but there is still a nurse caring behaviors that have not implemented the behavior in the process of nursing care services. Caring in nursing is a core part which is important especially in nursing practice because caring behaviorhas the basic values such as human concept, the concept of health, environmental concept, and the concept of nursing. So expect nurses can implement these behaviors in providing excellent service to the client, so the client also had the pleasure of getting good service. Nurses caring behavior behavior are influenced by several factors, one of them as an individual, organization, and leadership, so it is not easy to also implement the behavior depends on the willingness of the individuals themselves.

\subsection{Workload and Stress Relationship Work With Application Behavior Behavior Caring Nurses In Nursing Care Hospital Probolinggo In the Main Room.}

From the above results indicate that there is a relationship work load and work stress with the application of behavior nurse caring behaviors in the nursing care services in the main room Probolinggo Hospital. Provided that the value of $\alpha p$ value of 0.001 with a significance level of 0.05 . Thus, the $\mathrm{p}$ value is smaller than $\alpha(0.05)$ so that $\mathrm{H} 0$ rejected and $\mathrm{H} 1$ accepted.

According to Gillis (1999) high workload could increase the occurrence of poor communication between the $\mathrm{y}$ ang nurse with a patient, failure of collaboration between nurses and physicians, discharge nurses and nurse job dissatisfaction. To estimate the workload of nurses on a unit, the manager should collect data on: the number of patients admitted to the unit it every day / month / year, condition or level of dependency of the patients in the unit, the average days of treatment, the type of action required the patient, the frequency of each nursing actions are performed, the average time required to provide nursing actions It is very influential on the application of behavior nurse caring behaviors in the process of health care. This is evidenced by the results Trisna (2007) Activities nurses the most widely performed in the inpatient unit is in the process of nursing care services, so that the workload is closely linked to the process of nursing care services. And the factors that affect the workload among others, the number of patients, number of nurses, the amount of activity.

According to Gibson et al (2006), states that job stress is an adaptation response mediated by individual differences and or psychological process which is a consequence of any action from the outside (environment), situations, or events that define the psychological and or physical demands excessive to someone. 
According to Selye (2002) Job stress does not always produce bad results in human life. Differentiate stress into 2 of destructive distress and eustress which is a positive force. The stress required to produce high achievement. Similarly, the opposite of work stress can cause negative effects, but in general the symptoms caused by work stress have more adverse impact on nurses and patients. The adverse effects caused by stress is not applied nurses caring behavior behavior of nurses in the process of nursing care services.

Based on the above survey shows that nursing personnel decreased during the client's needs can lead to increased workload of nurses is increasing, resulting in a decrease of the quality of health services. High workload is very influential in implementing nursing care or nurse caring behavior behavior, with a high load, the client needs will not be met properly. From the results, the workload experienced by the main diruang nurse workload is moderate, so the nurse in the main room can apply caring behavior pelayanana behavior in the process of nursing care. To determine the workload of many factors that influence them is the level of dependency of patients, number of patients, nursing actions are given and the work environment.

While the stress experienced by nurses in the main room is the stress being so nurses can implement the behavior in the caring behavior of nursing care services. There are many factors that affect a person's level of stressor, one of which is the level of education, age of maturity a person, experience in working. The higher the level of education, experience, the level of the person's age, the more he can adapt in the face of stress in him, he could face the stressor with a variety of stress management. In accordance of the results obtained in the main room, the majority of nurses aged over 30 years so that the nurse can deal with stress easily without disturbing the activity in nursing care services. In addition to these factors there are many things that can affect the behavior of nurses in implementing caring behavior in the process of nursing care services among which workloads, nurses responsible tanggaung, volition, and awareness of the nurse.

\section{Conclusion}

1. Workload nurses in hospitals Main Probolinggo most of the workload being experienced.

2. Work Stress in the Main Room nurse Hospital Probolinggo mostly experienced moderate job stress.

3. Caring nurse behavior in the main hall of Probolinggo hospitals caring mostly behaved.

4. There is a relationship workload and stress of work with the application behavior nurse caring behaviors in the nursing care service in the Main Room hospitals Probolinggo. 


\section{Macrothink \\ International Journal of Human Resource Studies \\ ISSN 2162-3058 2015, Vol. 5, No. 3}

\section{Suggestions}

\section{For Nursing Profession}

Always apply the behavior expected of nurses caring behavior in the process of nursing care services, because caring is the primary duty nurse, so clients can get good customer service and caring behavior can accelerate the healing process for clients.

\section{For Educational Institutions}

Provide learning to students so that students can also apply a behavior caring behavior in the process of nursing care services, so that students can apply caring behavior behavior in the field of health care during practice.

\section{Land for Practice}

So that the activities of the process of nursing care nurse caring behaviors can always apply the behavior of nurses in the health service.

\section{For the Respondents}

Can provide insight into the behavior of nurses in the health care process, so that the client and the nurse can do a good relationship during the process of health care. Clients will feel satisfied with the services provided by nurses in particular.

\section{For researchers}

Can add insight for researchers how important caring behavior apply the behavior on the client, so that nurses can provide excellent service in a nursing care service, so that no nurse is synonymous with the word jutek, nasty, bitchy.

\section{For Further Research}

Researchers are expected to further develop and expand this research, so this study can be used as an input to conduct further research.

\section{References}

Salam (2008). Nursing Research and Scientific Writing Techniques, Jakarta: SalembaMedika. Arikunto, Suharsimi. (2005). Research Procedure A Practice Approach, Jakarta: Ghalia Indonesia.

Christerisen, PJ \& Kenney J. (2006). Nursing process aplication of conceptual models, 4th edition. St. Louis: The CV Mosby Company

George, Julia B. (2004). Nursing theories: the base for professional nursing practice, 4th edition. Connecticut: Apleton\& Lange

Gibson et al. (2006). Hand book of critical care nursing. Canada; Fleschnerpublisingcomany 


\section{Macrothink}

International Journal of Human Resource Studies ISSN 2162-3058 2015, Vol. 5, No. 3

Hidayat. (2004). Psychiatric treatment guidelines stress models modifications, Pusdinakes, jakarta

Nursing Journal of Indonesia, 2012.The impact of workload on health care.

Khan et al. (2005). Organizasional behavior (third edition) orlando, Harcour brace and company

Kozier, B., Erb, G., Berman, AJ, \& Snyder. (2004). Fundamentals of Nursing: Concepts, Process, and Practice. 7th Ed. New Jersey: Pearson Education, Inc.

Margiati. (2009). Organizational behavior, edition 2, Jakarta

Morgan \& king. (2006). Understanding stress the historical perspective, champan and hall, london.

Munandar. (2005). Social psychology for nurses. EGC, Jakarta.

Natsir, JE (2008). Performance Implement Nursing Care Nurses In Hospital And Factors Affecting. accessed July 12013

Nursalam. (2008). Concept and Implementation Methodology of Nursing Research, Jakarta: SalembaMedika.

Nursalam. (2008). Process and Documentation of Nursing: Concepts and Practice. SalembaMedika. Jakarta

Nuralam and SitiPariani. (2008). Methodology of Nursing Research, Jakarta: as great Seto.

Potter \& Perry, (2005). Fundamentals of Nursing Fundamentals of nursing, Book 1 Edition 7, Editor Dripasjabana, SalembaMedika, Jakarta

Potter, PA \& Perry AG (2005). Fundamentals of Nursing: Concepts, Process, and Practice. 6th Ed. St. Luois, MI: Mosby Elsevier.

Setiadi. (2007). Methodology of Nursing Research. Graha Science, Yogyakarta

Swanson, KM (2004). Nursing as informed caring for the well-being of other image: The Journal of Nursing Scholarship. 25 (4). 352-357).

Vance, T. (2007). Caringand the professional practice of nursing. Accessed on 01 July 2013.From http://www.proguest.com/pqdweb.

Watson, J. (2004). Caring Science as Sacred Science. Philadelphia: FA Davis Company.

Watson, J. (2006). Assesing and measuring caring in nursing and health sciences: FA Davis Company. 